\title{
Estatuto da criança e do adolescente: avaliação histórica
}

\author{
A. F. Amaral e Silva
}

\section{RESUMO}

\begin{abstract}
O Estatuto da Criança e do Adolescente completa dez anos de existência e ainda sofre uma série de críticas por parcela da sociedade que ainda resiste à mudança de paradigma em relação à criança e ao adolescente. Para muitos é mais cômodo continuar vendo as crianças e adolescentes como "menores", ou seja, incapazes de serem sujeitos de sua história. No entanto, tendo por base a Doutrina das Nações Unidas para a Proteção Integral e a Constituição Federal Brasileira, o Estatuto aparece como uma resposta humanitária à injustiça vivida por milhares de crianças e adolescentes em situação de vulnerabilidade, pela precária situação da saúde, da educação, do desrespeito à liberdade, à dignidade e à convivência familiar e comunitária, possibilitando-lhes ascender ao status de cidadãos.
\end{abstract}

Palavras-chave: Estatuto da Criança e do Adolescente, sujeito de direito, cidadania.

\begin{abstract}
The Statute of Children and Teenagers'has become 10 years old., and it has been criticized by a society which can't be submitted to paradigmatic changes concerning children and teenagers. It is very easy to see children and teenagers as " minors", i.e., not able to be responsible for their history. However, the Statute comes as a humanitarian response to lack of justice suffered by vulnerable children and teenagers, based upon the Doctrine of the United Nations . These children and teenagers are vulnerable due to their poor health and education, lack of respect concerning freedom, dignity and familiar and communitary living conditions. Their Statute is a way of bringing them back to citizen ' status "

Key-words: Statute of Children and Teenagers', rights, citizenship.
\end{abstract}

\section{Introdução}

A avaliação histórica do Estatuto da Criança e do Adolescente, impõe retorno às suas fontes materiais e formais, indispensável à exegese das novas normas.

A interpretação dos fenômenos decorrentes da radical mudança de ótica em torno do relacionamento da família, da sociedade e do Estado relativamente às crianças e adolescentes, para ser útil, precisa vir colorida pela crítica.

De portadores de necessidades, verdadeiros objetos de tutela, crianças e adolescentes passam a ser encarados como sujeitos de direito, portadores de todos os direitos fundamentais e sociais, inclusive o de responderem pelos seus atos.

A radical mudança não poderia ser recebida sem resistências.

A família, principalmente os pais, titulares do pátrio poder, não assimilam, de pronto, a nova postura.

Oposições continuam se manifestando fortemente, inclusive na sociedade, todos acostumados à cômoda posição de encarar crianças e adolescentes como "menores", dependentes, imaturos, necessitados de "proteção", numa palavra, incapazes. Proteção traduzida em medidas autoritárias justificadas pelo "superior interesse do menor", quase sempre concretizada na "tirania" dos pais sobre os filhos.

O "superior interesse" da educação persiste mito conveniente, justificando violências, inclusive físicas, no recesso dos "lares", onde, ainda, lamentavelmente, predomina o autoritarismo dos "adultos" e onde, em nome do "amor", continuam se praticando iniquidades contra os mais vulneráveis. 
O Estatuto, tendo por fonte material o fenômeno da violência contra crianças e adolescentes e a chamada "questão do menor", aparece como resposta humanitária à injustiça vivida por milhões de seres em situações de vulnerabilidade.

A falta de atenção à saúde; à educação; o desrespeito à liberdade, à dignidade e à convivência familiar e comunitária; o descaso pela educação, pela cultura, pela profissionalização, pelo esporte e pelo lazer; obrigam uma elaboração de normas capazes de garantir coercivamente os direitos de nossa maior riqueza, as crianças.

As leis não nascem por acaso, surgem dos fenômenos sociais, quando deveriam se originar das necessidades sociais.

O Direito Norma, via de regra, desponta criado pelos poderosos para garantir seus interesses, impostos coercivamente à obediência de todos, os chamados "escravos da lei", quando, na verdade, a lei é que deveria surgir escrava dos interesses humanos, principalmente dos mais vulneráveis.

O Estatuto, como o Código do Consumidor, as leis do meio ambiente, da economia popular, da usura, da ação popular, das ações civis públicas, nasce das necessidades sociais. Assim como suas congêneres, encontra resistências, interpretações equivocadas e, principalmente, má vontade, própria dos poderosos interesses contrariados.

Regulando a chamada democracia participativa através dos Conselhos de Direitos; interferindo na formulação de políticas públicas e no controle das respectivas ações; permitindo, inclusive, recurso ao Judiciá-rio, o Estatuto haveria de se defrontar com resistências, principalmente dos agentes políticos, desacostumados à co-participação comunitária.

Ao submeter pais e responsáveis a respostas pelo desrespeito, por exemplo, ao sagrado direito que têm as crianças, como pessoas humanas, à liberdade de opinião e de expressão; de crença e de culto religio-so; a buscar refúgio, auxílio e orientação, é claro que as novas disposições não poderiam ser bem recebidas por muitos adultos, acostumados às diretrizes e ordens dos "bons pais de família", solidificadas no poder decorrente de seculares práticas despóticas.

"Educadores", também habituados ao autoritarismo das cátedras, não vêem com bons olhos muitos dos novos direitos dos educandos, principalmente o de contestar critérios avaliativos e a possibilidade de recurso às instâncias escolares superiores, ou o direito de se organizar e de participar de entidades estudantis, bem como "o direito dos pais de terem ciência e participação no processo pedagógico".

Antigos Juizes de Menores, que possuem, inclusive, poderes legislativos; diversos Promotores de Justiça, tidos como defensores, Curadores de Menores e muitos Delegados de Polícia, que "sempre procuram o bem estar e o melhor para o menor", podendo agir sem limites, também se opuseram. Pois, de uma hora para outra, são obrigados a se submeterem à estrita legalidade, com formalidades processuais e outros incômodos.

Entidades Públicas e Privadas de "Proteção ao Menor", agora sujeitas à orientação, acompanhamento e fiscalização das comunidades através dos Conselhos e do Ministério Público, acostumadas ao autoritarismo, tendo de se adaptar, também criticam as novas normas e, em muitos casos, resistem com práticas da antiga doutrina da situação irregular.

Maquiavel aconselha a não se fazer mudanças radicais, coisas novas, sustentando que é muito perigoso, pois isso provocaria resistência e agressividade. Verdade incontestável. O Estatuto é visto pelos poderosos com desconfiança e com hostilidade. A desconfiança origina-se das profundas mudanças de concepção da infância e da juventude. Ao contrário do que muitos pensam (pelo fato de não conhecerem suas normas), o Estatuto não só garante direitos, mas também fixa responsabilidades para crianças e adolecentes, funcio-nando como um importante instrumento de pedagogia social.

A hostilidade parte principalmente dos antigos defensores da chamada "doutrina da situação irregular", inconformados com o novo sistema administrativo, descentralizado e participativo e com o novo sistema de justiça, garantista e responsabilizante.

O tempo, pouco a pouco, vem desmantelando resistências e hostilidades e o Estatuto começa a ser entendido e corretamente aplicado.

Organizaram-se seminários, debates, colóquios, onde direitos e responsabilidades são estudados a partir da ótica da cidadania. Os Conselhos de Direito vão se afirmando e os Conselhos Tutelares vêm adquirindo sua verdadeira identidade. Programas ao invés de instituições, principalmente voltados para o restabelecimento de direitos, para a família e para os vínculos comunitários, surgem como promissoras realidades dentro dos princípios preconizados pela Doutrina das Nações Unidas para a Proteção Integral. A tormentosa área da chamada delinqüência juvenil começa a ser encarada de forma realista e científica. Sucedem-se boas alternativas à institucionalização com resultados promissores. 
Tribunais, Juizes, Ministério Público, Assistentes Sociais, Educadores, Psicólogos passam a interpretar o Estatuto com base nos postulados da Doutrina das Nações Unidas, fonte formal das novas disposições.

Crianças e adolescentes são encarados como verdadeiros sujeitos de direito.

Constantemente vê-se crescer o interesse em torno das novas regras. A Lei, como norma coerciva, é vista como importante instrumento de avanço e conquista social. Ganha espaço a pedagogia de direitos e de responsabilidades. A cidadania é valorizada em ampla e profícua discussão. O Estatuto, como as demais leis, contém apenas normas abstratas. Por si só nada resolve. No dizer do Desembargador Marcel Hope, não passa de uma receita que precisa ser aviada corretamente. A interpretação e aplicação correta está ligada às fontes formais do documento brasileiro, os tratados internacionais de direitos humanos das Nações Unidas.

A avaliação do Estatuto, nesses 9 anos de vigência, resulta positiva, não fosse pelas centenas de ações civis públicas que garantem direitos fundamentais e sociais, seria pela nova postura dos adultos frente às crianças, que passam a ser encaradas como sujeitos de direitos, principalmente da prioridade absoluta e da proteção integral. 